To cite this article: Jibril Attahiru Alhassan, Lawal Abubakar, Musa Majaidu Ndayako, Fatimah Jibril Abduldayan and Katamba Abubakar Saka (2020) Knowledge Acquisition System of Traditional Crafts in Bida and Gusau Towns in Northern Nigeria. Information Impact: Journal of Information and Knowledge Management, 11:3, 12-21, DOI: dx.doi.org/10.4314/iijikm.v11i3.2

To link to this article: https://dx.doi.org/10.4314/iijikm.v11i3.2

\title{
Knowledge Acquisition System of Traditional Crafts in Bida and Gusau Towns in Northern Nigeria
}

\author{
${ }^{1}$ Jibril Attahiru Alhassan ${ }^{2}$ Lawal Abubakar ${ }^{3}$ Musa Majaidu Ndayako ${ }^{1}$ Fatimah Jibril \\ Abduldayan and ${ }^{1}$ Katamba Abubakar Saka \\ ${ }^{1}$ Department of Library and Information Technology, Federal University of Technology, Minna \\ ${ }^{2}$ Federal University Library, Birnin Kebbi \\ ${ }^{3}$ Federal Polytechnic Library, Bida
}

\begin{abstract}
This study investigated knowledge acquisition and transfer system among traditional crafts in Bida and Gusau towns in Northern Nigeria. Five research questions guided the study and include variables such as types of crafts practiced, sources of knowledge and skills; people involved sustainability and challenges to traditional crafts in the two towns. Case study was used with population of all traditional craftsmen in Bida and Gusau (Niger and Zamfara States) respectively. A sample size of 90 craftsmen was drawn through stratified random sampling. Descriptive statistics involving frequency counts and percentages were used to analyze the collected data. Results showed that embroidery and blacksmithing were the major crafts practiced; knowledge and skills were obtained through inheritance/initiation and that the unemployed were the major craftsmen. Other findings include "no alternative' jobs as a factor that sustain traditional crafts and that limited capital was the major obstacle to traditional crafts in the two towns. The study recommended amongst others the inclusion of limitless type of crafts to various skills through formal education, vocational training, apprenticeship, etc.
\end{abstract}

Keywords Traditional crafts, Apprenticeship,

Knowledge, Skills, Nigeria

CONTACT Alhassan,J.A.,Abubakar,L.,Ndayako,M.M.,Abduldayan,F.J and Saka,K.A j.alhassan@futminna.edu.ng

Department of Library and Information Technology, Federal University of Technology, Minna, Nigeria 2020 The Authors Published with License by Information Impact

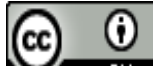




\section{Introduction}

Traditionally, Africans educate their youths through a systematic and organized apprentice system. Although Nigeria consists of many ethnic groups and societies each with its own culture and tradition, they all have common educational aims and objectives. However, the method differs from place to place, chiefly because of social, economic and geographical variation. Knowledge and skills acquisition and transfer system among indigenous craftsmen is a contractual agreement undertaken by the master craftsmen and apprentice where the apprentice is trained for a prescribed work process practical experience under the supervision of the mastercraftsmen. It is a form of work-place learning, which enables the apprentice to have on-the-job training. Every society, whether simple or complex, has its own system of training and educating its youth. However, the goal of education and the method of approach may differ from place to place, nation to nation and people to people.

In Africa, apprenticeship has been an age-long method used in training young people in the area of trades, crafts, agriculture, business, and catering. Vocationally, training in traditional society is largely run on apprenticeship system and is a time-honored initiative educating millions of African youths and adults. Usually children are not trained by their parents but by relatives, master craftsmen in particular field or friends in order to ensure discipline and concentration. This is a common feature of the traditional setting to see people engage in a vocation such as farming, fishing, hunting, carving and so on. This system which is referred to as apprenticeship is guided by customs lineage and rituals. According to Adekola (2013) there was no established system of skill development for the Youths in Africa. He cited Osokoya (1989) who observed that "all learning activities were integral part of the indigenous education learnt through observation, imitation and constant practice. The idea of organized and progressive training was not known. The Youths then were compelled to learn the family work as opportunity to learn work outside one's family was almost not available i.e apprenticeship system was not known". Thus, apprenticeship in training system began as part of a wide education process in which indigenous society of Nigeria passed on their cultural heritage from one generation to the next. The skill owned by a family was highly valued, and in some lines such as native medicine secrets were zealously guarded, as they are indeed today. Evidence of the passing on of skills within families is still strong.

Knowledge and skill are seen by many as a key source of competitive advantage and innovation in organizations. Therefore, it becomes very pertinent to ensure their effective management. Libraries play central role in the acquisition, management and accessibility of indigenous resources. In a research conducted to determine how libraries in Oyo state, Nigeria provide access to indigenous knowledge resources and challenges involved, Adeniyi and Subair (2013) reported that there are different means of providing access to indigenous knowledge and none of the libraries provide access to indigenous knowledge through public access database.

Nigeria is a multiethnic society, politically divided into six geopolitical zones and made up of 36 States. The North West and the North Central geopolitical zones are made up of seven and six states respectively. Bida is a major ancient town in Niger state in North Central while Gusau is the capital of Zamfara state in North West. In both Gusau and Bida, people are engaged in a variety of vocational activities and receiving training by observing elders and experts and through instruction given by them e.g. farming, leather work, fishing, animal care, weaving, blacksmithing, cooking, and carving etc. The people of Bida are mainly Nupes while the people of Gusau are mainly Hausa/Fulani by tribe. Traditionally, these people are majorly farmers with some craftsmen in their midst such as blacksmiths, brass smiths, wood carvers, herbalists, dyers, leather tanners, fishermen, weavers, barbers etc. most of these people are getting old and transfer of their skills and knowledge to coming generations become imperative. 
The knowledge possessed by craftsmen need to be transferred to other generations. However, modernization has led to rural-urban migration in Nigeria. The consequence is the neglect of the traditional practices and trades by the youth. In addition to the above, the present economic situation in the world is a thing of worry. In Nigeria, many educated youths are faced with the difficulty of gainful employment many years after graduation. The alternative to this is the development of entrepreneurial skills among graduates which have also been incorporated in the curriculum of tertiary institutions. Ezenwakwelu, Egbosionu and Okwo (2019) submitted that apprentices acquire technical and entrepreneurial skills for self-employment through formal and informal apprenticeship training systems.

However, our indigenous communities have crafts and occupations based in the rural and semiurban settings that could still be taped and transformed into gainful employment by youths through appropriate skills acquisition and knowledge transfer system. It is against this backdrop that this study investigates knowledge and skill acquisition and transfer system among the indigenous craftsmen in Bida, Niger State and Gusau in Zamfara State.

\section{Objectives of the study}

The specific objectives of the study are to:

1. Determine the types of crafts that are practiced in Bida and Gusau.

2. Identify the categories of people mostly engaged in the traditional crafts in the two towns.

3. Identify the sources of knowledge and skills for the craftsmen in the two towns.

4. Determine factors that sustain traditional crafts in the two towns.

5. Identify the challenges to the acquisition of skills and knowledge transfer of traditional crafts in the two towns.

\section{Literature review}

Several studies have been carried out on the issue traditional knowledge acquisition and transfer system especially in Africa. For example, Camble and Aliyu (2008) investigated indigenous knowledge of Soye community in Bama Local Government Area of Borno state in Nigeria. Structured interview schedule was used in data collection in the aspects of availability, use dissemination and documentation of indigenous knowledge. Results of the interview showed that the people of Soye practice history and culture, agriculture, education, health, local crafts/industry and leisure/recreation. Soye people practice local crafts and industry such as blacksmithing, poetry, calabash works, hide and skin works, weaving and knitting of caps, etc.

Dissemination of indigenous knowledge is largely through traditional instruction method, observation, participation and apprenticeship. The custodians of indigenous knowledge were mostly the traditional rulers, elderly people and professionals in various vocations. Indigenous knowledge are documented in peoples' memories, practices and activities, shared and communicated orally. Ntui and Ottong (2008) conducted a similar study to determine the dissemination of indigenous knowledge among Raffia artisans in Ikot Ekpene Local Government Area of Akwa Ibom State, Nigeria. Data was collected through oral traditions, questionnaire, interviews and observations. Results showed that raffia craft knowledge is stored in people's memories and activities and expressed in the form of stories, songs, and dances which are transmitted orally. Skills are passed from master to apprentices or from parent to child.

A collaborative research was conducted by Ezeani, Ugwu and Ozioko (2008) to determine the role of librarians as knowledge managers. It was reported that the critical roles of librarians as knowledge managers include those of information providers and custodians of information. Matthew, Uper and Denen (2016) investigated the utilization of knowledge management tools and method in Federal University of Agriculture, Makurdi using professional and paraprofessional staff of the university library as the study population. Results showed that 
majority of the respondents indicated "knowledge cluster" for identifying knowledge; collaborative virtual workspaces as creating, storing and applying knowledge; computers for sharing knowledge and that they were very dissatisfied in using knowledge management methods and tools respectively. Major barriers to KM methods and tools were financial pressures.

There has not been any empirical study on the pattern of knowledge management systems for traditional crafts of the two ancient cities of two major ethnic groups in northern Nigeria. It is that gap in knowledge that this study is set to fill.

\section{Methodology}

The research method adopted in this research is the survey research design. This design is adopted for this study because it involves information collection from people with diverse crafts within two municipalities. The population of the study consisted of all craftsmen in Gusau town in Zamfara State and Bida town in Niger State, which could not be defined due to unavailable national data on the number of registered craftsmen in any community. Stratified random sampling technique was used to cater for all crafts and also to take care of gender and age groups. Seventy craftsmen were sampled in Gusau and thirty from Bida giving a total of one hundred. In a study of this nature, illiterates are mostly involved; as such the data collection instrument used was a structured questionnaire. The questionnaires was divided into two different sections; Section A dealt with demographic characteristics of the respondents while Section B dealt with the variables of the study. The questions were read and interpreted to the respondents in Hausa or Nupe by the researchers and answers were ticked or circled appropriately. Data collected were analysed using frequency count and simple percentage.

\section{Results}

Respondents' demographic analysis

Table 1: Questionnaire Return Rate

\begin{tabular}{lccc}
\hline Town & $\begin{array}{l}\text { Copies of Questionnaire } \\
\text { Administered }\end{array}$ & Copies of Questionnaire returned & Percentage (\%) \\
\hline Bida & 50 & 30 & 60 \\
Gusau & 70 & 60 & 86 \\
\hline Total & $\mathbf{1 2 0}$ & $\mathbf{9 0}$ & $\mathbf{7 5}$ \\
\hline
\end{tabular}

A total of 50 copies of questionnaires were distributed among the respondents in Bida out of which $30(60 \%)$ were returned and found usable; while 70 copies were distributed in Gusau, out of which 60 (86\%) were completed and returned and found usable. The copies of questionnaire distributed in the two towns were 120 out of which 90 representing $75 \%$ were returned and found usable.

Table 2: Gender distribution of respondents

\begin{tabular}{llll}
\hline Town & Male & Female & Total \\
\hline Bida & $24(80 \%)$ & $6(20 \%)$ & $30(100 \%)$ \\
Gusau & $43(72 \%)$ & $17(28 \%)$ & $60(100 \%)$ \\
\hline Total & $\mathbf{6 7 ( 7 4 \% )}$ & $\mathbf{2 3 ( 2 6 \% )}$ & $\mathbf{9 0 ( 1 0 0 \% )}$
\end{tabular}

From the table above, it is shown that in the two towns under study, male craftsmen are more than their female counterpart. This is attributed to the fact that some craft works like blacksmithing, hart weaving, etc are dedicated or carried out by male. Moreover, in 
many Muslim dominated communities in northern Nigeria, Women are more involved in petty trades at home while men are more involved in crafts and farming.

Table 3: Age distribution of respondents

\begin{tabular}{|c|c|c|c|c|}
\hline Town & $\begin{array}{l}20 \text { years and } \\
\text { below }\end{array}$ & $21-40$ years & 41years and above & Total \\
\hline Bida & $4(13 \%)$ & $12(40 \%)$ & $14(47 \%)$ & $30(100 \%)$ \\
\hline Gusau & $9(13 \%)$ & $20(32 \%)$ & $31(55 \%)$ & $60(100 \%)$ \\
\hline Total & $13(14 \%)$ & $32(36 \%)$ & $45(50 \%)$ & $90(100 \%)$ \\
\hline
\end{tabular}

Table 3 shows that $14(47 \%)$ of respondents from Bida were above 40 years of age, while $31(55 \%)$ respondents from Gusau were above 40 years of age, this gives a total of $45(50 \%)$ of the respondents that were 41years and above. The table further revealed that $12(40 \%)$ of the respondents from Bida were between 21-40 years of age as against 20(32\%) respondents from Gusau in the same age bracket with a total of $32(36 \%)$. The table also shows that $4(13 \%)$ of the respondents from Bida were 20 years or below, and 9(13\%) respondents from Gusau were also 20 years or below giving a total of $13(14 \%)$.

Table 4: distribution of respondents by years of experience

\begin{tabular}{lllll}
\hline Town & $\begin{array}{l}\mathbf{1 0} \text { years and } \\
\text { below }\end{array}$ & $\mathbf{1 1 - 2 0}$ years & 21years and above & Total \\
\hline Bida & $3(10 \%)$ & $8(27 \%)$ & $19(63 \%)$ & $30(100 \%)$ \\
Gusau & $30(50 \%)$ & $23(38 \%)$ & $7(12 \%)$ & $60(100 \%)$ \\
\hline Total & $\mathbf{3 3 ( 3 7 \% )}$ & $\mathbf{3 1 ( 3 4 \% )}$ & $\mathbf{2 6 ( 2 9 \% )}$ & $\mathbf{9 0 ( 1 0 0 \% )}$ \\
\hline
\end{tabular}

Table 4 shows that 19(63\%) respondents in Bida had over 21 years of experience with only $3(10 \%)$ having 10 years or less of experience. In Gusau, 45(50\%) of the respondents had 10 years and below years of experience. In all, 33(37\%) of the total respondents had 10 years or below experience, 31(34\%) had between 11 and 20years experience and 26(29\%) had over 21 years experience.

\begin{tabular}{|c|c|c|c|c|c|}
\hline Town & $\begin{array}{l}\text { Islamic } \\
\text { only }\end{array}$ & Education & Basic and Secondary Education & $\begin{array}{l}\text { Tertiary } \\
\text { Education }\end{array}$ & Total \\
\hline Bida & $9(30 \%)$ & & $8(27 \%)$ & $13(43 \%)$ & $30(100 \%)$ \\
\hline Gusau & $27(45 \%)$ & & $31(52 \%)$ & $2(3 \%)$ & $60(100 \%)$ \\
\hline Total & $36(40 \%)$ & & $39(43 \%)$ & $15(17 \%)$ & $90(100 \%)$ \\
\hline
\end{tabular}

Respondents in Bida have the highest percentage of $43 \%$ in tertiary education while Gusau boast of $45 \%$ of Islamic education only. However, in both towns, respondents are seen to have both basic and secondary education as reflected in their percentages of Bida $27 \%$ and Gusau $52 \%$. 
Table 6: Distribution of respondents by types of craft practiced

\begin{tabular}{llccc}
\hline $\mathrm{S} / \mathrm{N}$ & Craft & Bida (Niger State) & Gusau (Zamfara State) & Total \\
\hline 1 & Glass work & 3 & 0 & $3(3 \%)$ \\
2 & Brass work & 3 & 0 & $3(3 \%)$ \\
3 & Embroidery & 4 & 12 & $16(18 \%)$ \\
4 & Pottery & 2 & 3 & $5(6 \%)$ \\
5 & Cloth weaving & 2 & $3(6 \%)$ & $7(8 \%)$ \\
6 & Cap making & 2 & 5 & $15(17 \%)$ \\
7 & Black Smithing & 5 & 10 & $13(14 \%)$ \\
8 & Tying and dying & 2 & 11 & $10(11 \%)$ \\
9 & Calabash making & 3 & 7 & $5(6 \%)$ \\
10 & Barbing/Hair plating & 2 & 3 & $4(4 \%)$ \\
11 & Wood carving & 2 & 2 & $4(4 \%)$ \\
12 & Skin Tanning & 0 & 4 & $90(100 \%)$ \\
\hline
\end{tabular}

Table 6 reveals that embroidery has the highest number of respondents of 16(18\%) followed by blacksmithing 15(17\%). Tying and dying had 13(14\%) respondents and calabash making $10(11 \%)$. Other crafts had less than 10 respondents each. From the table, it is also revealed that glass work and brass work were restricted to Bida town with 3(3\%) respondents each while skin tanning was restricted to Gusau town with 4(4\%) respondents.

Table 7: Categories of People that are mostly engaged in traditional craft

\begin{tabular}{llll}
\hline \multicolumn{1}{c}{ Categories } & \multicolumn{1}{c}{ Bida (Niger State) } & \multicolumn{1}{c}{ Gusau (Zamfara State) } & $20(22 \%)$ \\
\hline Family members only & $12(40 \%)$ & $8(13 \%)$ & $2(2 \%)$ \\
Family friends & $2(7 \%)$ & $0(\%)$ & $7(8 \%)$ \\
Any interested person & $7(23 \%)$ & $0(0 \%)$ & $27(30 \%)$ \\
Unemployed & $2(7 \%)$ & $25(42 \%)$ & $20(22 \%)$ \\
Those without formal education & $4(13 \%)$ & $16(27 \%)$ & $14(16 \%)$ \\
& & & $90(100 \%)$ \\
Less privileged & $3(10 \%)$ & $11(18 \%)$ & 60
\end{tabular}

Table 7 showed that unemployed people were the highest respondents $27(30 \%)$ that are mostly engaged in the traditional craft with majority from Gusau 25(42\%). This translates to mean that they have either experienced the labour market or feel satisfied with the traditional craft and hence do not care for government job. Furthermore, family members where the crafts are practiced and those without formal education were 20(22\%) each while 14(16\%) of the respondents are the less privileged people. Any interested people accounted for 7(8\%) and family friends accounted for $2(2 \%)$. 
Table 8: Source of Knowledge and Skills of respondents

\begin{tabular}{|c|c|c|c|}
\hline Source & Bida (Niger State) & Gusau (Zamfara State) & Total \\
\hline I obtained my skill through formal education & $0(0 \%)$ & $4(6.7 \%)$ & $4(4 \%)$ \\
\hline I went to a vocational centre for training & $2(7 \%)$ & $7(11.7 \%)$ & $9(10 \%)$ \\
\hline I was on apprenticeship for some years & $8(27 \%)$ & $15(25.0 \%)$ & $23(26 \%)$ \\
\hline $\begin{array}{l}\text { got the knowledge and skills through } \\
\text { inheritance/initiation from my family }\end{array}$ & $18(60 \%)$ & $17(28 \%)$ & $35(39 \%)$ \\
\hline I got my knowledge by imitation by practitioners & $0(0 \%)$ & $0(0 \%)$ & $0(0 \%)$ \\
\hline $\begin{array}{l}\text { Discuss with people in similar trade gain the } \\
\text { knowledge }\end{array}$ & $2(0 \%)$ & $11(18.3 \%)$ & $13(14 \%)$ \\
\hline $\begin{array}{l}\text { Participation in Community Association } \\
\text { meetings provided the knowledge }\end{array}$ & $0(0 \%)$ & $6(10.0 \%)$ & $6(7 \%)$ \\
\hline My knowledge was a Mystery & $0(0 \%)$ & 0 & $0(0 \%)$ \\
\hline Total & $30(100 \%)$ & $60(100 \%)$ & $90(100 \%)$ \\
\hline
\end{tabular}

From table 8 , it is revealed that $35(39 \%)$ of the respondents obtained their knowledge and skills through inheritance/initiation from their family, 23(26\%) obtained their knowledge and skills through apprenticeship, 13(14\%) by discussing with people in similar trade and $9(10 \%)$ through vocational centre. The table further reveals that $6(7 \%)$ of the respondents obtain their knowledge and skills from community association meetings and 4(4\%) through formal education. No respondent obtain the knowledge and skills through initiation or by mystery.

Table 9: Reasons for engaging in traditional craft

\begin{tabular}{llll}
\hline Reasons & Bida(Niger State) & Gusau(Zamfara State) & Total \\
\hline To be self employed & $11(40 \%)$ & $22(38 \%)$ & $33(37 \%)$ \\
To learn the trade & $1(0 \%)$ & $7(12 \%)$ & $8(9 \%)$ \\
To earn a leaving & $7(13 \%)$ & $20(33 \%)$ & $27(30 \%)$ \\
To sustain family trade & $11(47 \%)$ & $11(17 \%)$ & 0 \\
For the love of it & $0(0 \%)$ & $0(0 \%)$ & $\mathbf{9 0 ( 1 0 0 \% )}$ \\
\hline Total & $\mathbf{3 0}$ & $\mathbf{6 0}$ &
\end{tabular}

Table 9 shows that $33(37 \%)$ of the respondents are in crafts to be self-employed, $27(30 \%)$ respondents were in to craft, to earn a leaving and $22(24 \%)$ of the respondents were practicing the traditional craft to sustain the family trade. But no respondent is in to traditional craft for the love of it.

\begin{tabular}{|c|c|c|c|}
\hline Factors & $\begin{array}{l}\text { Bida (Niger } \\
\text { State) }\end{array}$ & $\begin{array}{l}\text { Gusau } \\
\text { (Zamfara } \\
\text { State) }\end{array}$ & Total \\
\hline $\begin{array}{l}\text { Conducive environment is one of the factors that sustained your traditional craft in the } \\
\text { town }\end{array}$ & $0(0 \%)$ & $6(10.0 \%)$ & $6(7 \%)$ \\
\hline $\begin{array}{l}\text { Patronage of your products is one of the factors that sustained your traditional craft in } \\
\text { the town }\end{array}$ & $8(27 \%)$ & $13(22) \%$ & $21(23 \%)$ \\
\hline Government is one of the factors that sustained your traditional craft in the town & $0(0 \%)$ & $0(0 \%)$ & $0(0 \%)$ \\
\hline $\begin{array}{l}\text { Satisfaction derived from it is one of the factors that sustained your traditional craft in } \\
\text { the town }\end{array}$ & $0(0 \%)$ & $17(28 \%)$ & $17(19 \%)$ \\
\hline Societal prestige is one of the factors that sustained your traditional craft in the town & $0(0 \%)$ & $4(7 \%)$ & $4(4 \%)$ \\
\hline $\begin{array}{l}\text { No alternative thing to do is one of the factors that sustained your traditional craft in the } \\
\text { town }\end{array}$ & $6(20 \%)$ & $20(33 \%)$ & $26(29 \%)$ \\
\hline $\begin{array}{l}\text { Mystery of knowledge transfer is one of the factors that sustained your traditional craft } \\
\text { in the town }\end{array}$ & $16(53 \%)$ & $0(0 \%)$ & $16(18 \%)$ \\
\hline
\end{tabular}

Table 10 shows responses on the factors that sustained the crafts, 26(29\%) of the respondents agreed that lack of alternative thing to do is the major factor of sustenance of the crafts, 21(23\%) 
of the respondents attributed the sustenance to patronage of their products, while 17(19\%) believed the sustenance is because of the satisfaction they derive from it. The table further revealed that $16(18 \%)$ of the respondents all from Bida attributed the sustenance of the crafts to mystery, 6(7\%) believed that conducive environment is a major factor of sustenance of the traditional crafts and 4(4\%) of the respondents attributed the sustenance to societal prestige. However, no respondent attributed the sustenance to government support.

\section{Table 11: Challenges faced by traditional craftsmen in the area}

\begin{tabular}{|c|c|c|c|}
\hline Challenges & $\begin{array}{l}\text { Bida(Niger } \\
\text { State) }\end{array}$ & Gusau(Zamfara State) & Total \\
\hline $\begin{array}{l}\text { Lack of knowledge and skills are challenges that are faced by } \\
\text { traditional craftsmen in your area }\end{array}$ & $0(0 \%)$ & $4(7 \%)$ & $4(4 \%)$ \\
\hline $\begin{array}{l}\text { Limited capital is one of the challenges that is faced by traditional } \\
\text { craftsmen in your area }\end{array}$ & $6(20 \%)$ & $15(25 \%)$ & $21(23 \%)$ \\
\hline $\begin{array}{l}\text { Lack of raw materials is one of the challenges that is faced by } \\
\text { traditional craftsmen in your area }\end{array}$ & $0(0 \%)$ & $5(8 \%)$ & $5(6 \%)$ \\
\hline $\begin{array}{l}\text { Low patronage is one of the challenges that is faced by traditional } \\
\text { craftsmen in your area }\end{array}$ & $1(3 \%)$ & $8(13 \%)$ & $9(10 \%)$ \\
\hline $\begin{array}{l}\text { Lack of government support is one of the challenges that is faced by } \\
\text { traditional craftsmen in your area }\end{array}$ & $1(3 \%)$ & $7(12 \%)$ & $8(9 \%)$ \\
\hline $\begin{array}{l}\text { Rural urban migration is one of the challenges that is faced by } \\
\text { traditional craftsmen in your area }\end{array}$ & $6(20 \%)$ & $4(7 \%)$ & $10(11 \%)$ \\
\hline $\begin{array}{l}\text { Western education is one of the challenges that is faced by traditional } \\
\text { craftsmen in your area }\end{array}$ & $2(7 \%)$ & $12(20 \%)$ & $14(16 \%)$ \\
\hline $\begin{array}{l}\text { Youths are no longer interested is one of the challenges that is faced by } \\
\text { traditional craftsmen in your area }\end{array}$ & $6(20 \%)$ & $5(8 \%)$ & $11(12 \%)$ \\
\hline $\begin{array}{l}\text { Mystery of transfer does not allow others to practice it is one of the } \\
\text { challenges that is faced by traditional craftsmen in your area }\end{array}$ & $8(27 \%)$ & $0(0 \%)$ & $8(9 \%)$ \\
\hline Total & $30(100 \%)$ & $60(100 \%)$ & $90(100 \%)$ \\
\hline
\end{tabular}

Limited capital was considered as the major inhibiting factor to traditional craft as revealed in table11 with $15(25 \%)$ from Gusau and 6(15\%) from Bida with an overall 21 (23\%). The table also showed that $14(16 \%)$ respondents considered western education as a major challenge, while $11(12 \%)$ considered lack of youths interest as a key challenge. The other challenges according to responses were rural urban migration $10(11 \%)$, low patronage $9(10 \%)$, lack of government support and mystery of knowledge transfer $8(9 \%)$, lack of raw materials $5(6 \%)$ and lack of knowledge and skills 4(4\%)

\section{Discussion}

Research question one sought to find out the types of crafts practiced in the two towns. The highest respondents indicated embroidery and blacksmithing as the two major traditional craft practiced in Bida and Gusau respectively. These two crafts are not only cheap to practice but also are considered as the major source of earning for the apprentice's livelihood. This finding corroborates the research findings by Camble and Aliyu (2008) who reported that Soye people in Bama LGA of Borno State practice among others the use of local crafts like blacksmithing, weaving and knitting of caps respectively.

Results on source of knowledge and skills acquisition revealed that apprentices obtained knowledge and skills through inheritance/initiation from their family. No wonder knowledge, experiences are passed from generation to generation by way of inheritance from parent/family members. This finding also corroborates those of Ntui and Ottong (2008), Camble and Aliyu (2008) but disagree with that of Ezeani, Ugwu and Ozioko (2008) respectively. The former coresearchers reported that the traditional rulers, elderly people and professionals in various vocations were the custodians of indigenous knowledge; documented in peoples' memories, shared and communicated orally. The later co-researchers reported the critical skills for librarians as knowledge managers to include ability to build schemes for the classification of information. 
It was discovered that the unemployed people were mostly engaged in the skills acquisition and knowledge transfer in traditional crafts. This could be the resultant effect on labour market whereby seeking government job becomes difficult. This finding contradict the findings of Ntui and Ottong (2008), Camble and Aliyu (2008) as well as Matthew, Uper and Denen (2016) respectively. The above researchers reported that the custodians of indigenous knowledge were mostly traditional rulers, elderly people and professionals in various fields of knowledge; librarians and para-professionals as well as apprentice respectively. The researchers specifically reported the type of artisans in the traditional crafts. On factors that help sustain the traditional crafts, majority of the respondents indicated there was no alternative thing to do and have resort to the traditional crafts. The respondents' belief that they cannot remain idle and hence need to find something for sustainable living. This finding is contrary to that of Ntui and Ottong as the co-researchers reported that skills are transmitted from master to apprentice or from parent to child.

With respect to challenges to the acquisition of skills and knowledge transfer in two towns, capital was the major obstacle. Money is required to procure the tools for the traditional crafts and convey the products to market. This finding is in conformity to those of Matthew, Uper and Denen (2016) as the co-researchers reported that apart from being very dissatisfied, professionals and para-professional in Federal University of Agriculture Makurdi library indicated financial pressure as the major bottleneck to KM and tools.

\section{Conclusion}

The study has revealed that apprentices practiced embroidery and blacksmithing and that the source of knowledge and skills acquisition were obtained through inheritance and initiation from family unemployed formed the bulk of traditional craftsmen in the two towns. However, limited capital was regarded as the major bottleneck to the knowledge and skills acquisition and transfer of knowledge among traditional craftsmen. The implication of the study is that the two practiced crafts act as the major source of earning their livelihood and with the passage of skills from generation to generation, knowledge would not be loss instead there would be an update in the knowledge modification. With the limited capital, the quality and quantity of crafts would negatively be affected as well as affecting the productivity level of the enterprise in the two towns.

\section{Recommendations}

Based on the findings, the study recommends that: -

1. Crafts practiced should not be limited to embroidery and blacksmith but rather opportunities be created to widen the scope so as to include glass and brass work, pottery, cloth weaving, cap making, dying, etc.

2. Traditional craftsmen in the two towns should be exposed to the acquisition of various skills through formal education, vocational training centres, apprenticeship initiation, etc.

3. Opportunities should be open to all categories irrespective of employed, priviledged, illiterate, etc.

4. There should be conducive environment, patronage, government support and societal prestige so as to sustain the traditional crafts in the two towns.

5. Assistance from the government is hereby needed to support traditional craftsmen in the two towns with financial assistance through loans. 


\section{References}

Adekola, G (2013) Traditional Apprenticeship in the Old Africa and Its Relevance to Contemporary Work Practices in Modern Nigerian Communities. British Journal of Education, Society \& Behavioural Science 3(4): 397-406

Adeniyi, A .I \& Subair, R .E (2013) "Accessing indigeneous knowledge in libraries and the problems. Library philosophy and practice: Lincoln (Oct 2013) http//digital commons. Unl.edu/lib philopractice. (E-journal)Paper 988.

Camble, E. \& Aliyu, Y. (2008). Indigenous knowledge: A case study of Soye community in Bama Local Government Area of Borno State, Nigeria. In Proceedings of the $46^{\text {th }}$ annual conference and AGM of the Nigerian Library Association, held at Arewa House Conference centre, Kaduna on June $1^{\text {st }}-6^{\text {th }}$ June, 2008.

Ezeani, C. N., Ugwu, C. I. \& Ozioko, R. E. (2008). Librarians as knowledge managers in the global library and information services: Empirical evidence from libraries in South Eastern Nigeria. In Proceedings of the $46^{\text {th }}$ National Conference and AGM of the Nigerian Library Association held at Arewa House, Kaduna on $1^{\text {st }}-6^{\text {th }}$ June 2008, 93100 .

Ezenwakwelu Charity A., Egbosionu Nneka A., \& Okwo Henry U. (2019)

Apprenticeship Training Effects on Entrepreneurship Development in Developing Economies. Academy of Entrepreneurship Journal, 25(1) 1-21

Matthew, C. T. Upev, M. T. \& Denen, N. K. (2016). Utilization of knowledge management tools and methods in university libraries in Nigeria: The case of Federal University of Agriculture, MAkurdi (FUAM). International journal of Applied Technologies in Library and Information Management, 2(1), 4-36.

Ntui, A. I. \& Ottong, E. J. (2008). Towards global dissemination of indigenous knowledge: the case of Raffia artisans in Ikot Ekpene Local Government Area of Akwa Ibom state, Nigeria, In Proceedings of the $46^{\text {th }}$ annual conference and AGM of the Nigerian Library Association, held at Arewa House Conference centre, Kaduna on June $1^{\text {st }}-6^{\text {th }}$ June, 2008. 85-92.

Ugwu, C.I (2008).Rural farmers and agricultural information transfer in developing countries. The potentials of mobile phone technology. journal of information resource management, $1(2), 108-116$ 